\title{
PROGRESSIVE CREATION
}

\author{
IN ATTEMPT AT A NEW APPROACH TOWARDS THE PROBLEM \\ CREATION - EVOLUTION
}

\section{THE MATERIAL}

1. Gen. 1 and 2

\section{A. THE OLD TESTAMENT}

Our main problem here is the relationship between these two chapters.

Many scholars hold that there is an irreconcilable discrepancy letween Gen. 1 and 2, or more precisely between Gen. 1-2 : 4a (or 4) and Gen. $2: 4 \mathrm{~h}(5)$ to the end of Gen. 3 . The first document is ascribed to $P$ and the second to $\mathrm{J}$.

For our purpose it is not necessary to give a detailed description of the alleged differences in style and subject matter. N. H. Ridderbos says that in a sense it cannot be denied that Gen. 2 offers an arrangement markedly different from that of Genesis 1. I agree with his solution that the author of Gen. 2 relates about creation just as much as is necessary for his purpose: namely to offer an introduction to what follows. If the author selects his materials with a specific purpose in mind, then it is also acceptable that his description follows a sequence determined by the same purpose. In other words, he does not mean to say that the works of creation took place in the order in which he now relates then.')

Von Rad stresses the fact that in Gen. 2 and 3 man is the centre of interest. Therefore his creation is related first. In Gen. 1 man is the summit of a pyramid and in Gen. 2 the centre of a circle. In accordance with his point of view he superscribes Gen. $2: 4 \mathrm{~b}-25$ with the title: Die jahwistische Geschiclfte von Paradies. ${ }^{2}$ ) The whole of chapter 2 (from verse 4 ) is introductory to the description of paradise and fall. For our purpose it is especially $2: 7$ that needs treatment-the creation of man.

\section{Creation in the rest of the Old Testament}

Usually the whote argument in connection with creation is concentrated on Gen. 1 (and perhaps sideways on Gen. 2). It should not be forgotten, however, that the theme is also treated in other books of the Old Testament, although not in such a systematic way.

a. The prophets.

Brongers $^{1}$ ) comes to the conclusion that there is not a single tradition of creation in the prophetic books of the Old Testament showing 
any essential difference with the record in Gen. $1: 1$ to $2: 3$, although "creation" occupies only a modest place in the pronouncements of the prophets.

The relevant texts are:

(i) Amos 4:13, cf also 9:6.

The admonition of verse $12 \mathrm{~b}$, is accentuated by reference to the omnipotence of God in different fields, in the first instance as Creator. This is seen in connection with His omniscience. $\left.{ }^{2}\right)$ It strikes one that Amos has his own vocabulary, e.g. 'êfá $(h)$ instead of hósè for darkness; 'agudda instead of ráqia'. Does this perhaps point to a different tradition or revelation?

(ii) Anos $5: 8$

Here God is described as the Creator of the stars. The two star complexes which are mentioned especially are Pleiades and Orion. They represent here the whole astral world.

(iii) Amos $9: 3$. Cf. also Is. $51: 9-10$; Job $9: 13 ; 26: 12$; Ps. $89: 10,11$. In these verses the word náhišs, snake, is not found, which is the case in Is. $27: 1$. Evidently the prophets here use the language of mythology (as in other places ráhál, liujátán, tannin etc.), according to which the gods in the beginning battled with an underworld noonster. According to Amos this monster is in any case an instrument of Jahwe. For a discussion of the question whether this figurative language refers to something that really happened, cf. $\S$ IV. A.

Isaiah $27: 1$.

This is the only relevant text in the first part of Isaial. The prophet describes the judgment of God over the three empires of lis time. It is very difficult to identify these empires with any precision. So much is certain, however, that motives of mythology, more especially those that depict a battle of the gods with "chaos" monsters, are utilized in the prophecy concerning an ordeal over some empires of the future. In our text are mentioned: liwjátán, the quick or "flecing" Snake, liwjatán, the coiling, twisting Snake, and tannin (a dragon of the sea).

Tannin is found as mythological sea monster in Job $7: 12$; Ps. 71: : 13; Is. 51 : 9; In Ezek. Pharaoh Hofra is addressed as the great tannin. It is important to notice that the idea is that just as there was a battle in primeval times, it is also repeated in historical times and will again take place in the eschatological period. Cf. also Is. $51: 9,10$.

The second part of Isaiah.

Here the revelation concerning Jahwe as the Creator-God plays a very important rôle. ${ }^{3}$ ) This is one of the most important themes in the second part of Isaiah. It is not necessary for our purpose to discuss all the texts. 
In this connection we refer mainly to the dissertation of B. J. van der Merwe ${ }^{4}$ ) where the matter is treated thoroughly from the point of view of the writer. After having surveyed the material, his conclusion is: (1) I) Itero-Isaiah does not present a doctrine of creation. The idea of creation has a ministerial function and is an element in a wider context.

(ii) Deut. Jes. presupposes knowledge of the creative power of Jahwe.

(iii) In several places where the idea of creation is found it has connection with the relation of Israel and/or Jahwe to other nations.

$V$ an der Merwe evidently agrees with many writers who acknowledge that in Gen. 1 much ancient material is incorporated. He points out that there is great similarity in the use of words between Ezekiel and Jeremiah $(27: 5)^{5}$ ) and sees the following points of correspondence between the second part of Is, and Gen. $1-3$ :

a. 'The use of the verb bira' for the creation of the heavens (Is. $42: 5 ; 45: 18$, cf. Gen. $1: 1 ; 2: 4$ a) and the earth (Is. $45: 12$; $43: 7$, cf. Gen. $1: 27 ; 5: 1 ; 6: 7$ ). Nowhere in these texts, however, is there a literal quotation from Gen. $1-3$.

b. As Gen. 1 : 2 Isaiah (45: 18c) uses the word tóhu.

c. $\Lambda$ s Gen. $1: 3$ Isaiah knows Jahwe as Creator of light.

d. As Gen. 1 : Of. Isaiah $(44: 27)$ evidently also reveals the fact that the dry land emerged out of the primeval waters.

P. Is. 51 : 9-10a can in a measure remind one of the division of the waters at creation. But the prophet speaks in terms of the mythological hattle of the gods, an element which is not found expressis verbis in Gen. 1. Is. 51 : 9f. mentions the names of the monster that is vanquished: rahib, tannin, jam (sea). The writer of Gen. 1 also uses the word tannin, but then as creation of God (cf. Gen. 1 : 21).

As in Gen. 1 : 14-19, Is. (40:25f; $45: 12)$ knows Jahwe as Creator of the world of stars and also the idea of order in the astral world. But there are great differences in words and thoughts.

The following differences are noted by Van der Merwe: (i) Is. 4.5 : 7 : Here Jahwe is the Creator (bóré) of darkness and disaster. Gen. 1 says nothing about the creation of darkness. Only the creation of light is mentioned. Is. 45 : 7 clearly militates against dualism. Van der Merwe, however, sees no essential theological difference between Gen. 1 and Is. 45. In both Jahwe is Lord over light and darkness. Also in Gen. 1 there is a renunciation of dualism in the stressing of the creative Word of God. But in Is. 45 this is clearer. In any case the difference between Gen. and Is. here is not of a fundamental nature. The fact that in Is. there are strong reminiscences of the battle of gods as a picture of creation, cf. e.g. Is. $\left.51: 9 f,{ }^{6}\right)$ is proof of this. 
Jeremiah.

The relevant texts are: $5: 22 ; 10: 12 f$; $27: 5 ; 31: 35 ; 32: 17$; $33: 25$ and $51: 15$. In all these texts there are clear reminiscences of Gen. 1. It is not necessary to point this out in detail.

b. The hymnic portions of the Old T'estament.

Van der Merwe comes to the conclusion that practically all the thoughts of Dt. Isaiah are found in the hymnical portions of the O.T.7)

(i) Is. $40: 12$-Job $28: 25 ; 38: 4$ f.

(ii) Is. $40: 22 \mathrm{a}$.

This motive is found passim in the hymnical literature of the O.T. (cf. Ps. $11: 4 ; 14: 2$; etc.).

(iii) Is. $40: 22 \mathrm{~b} ; 42: 5 \mathrm{a} ; 44: 24 \mathrm{~b} ; 51: 13 \mathrm{a}$. The idea that God spreads out the heavens is found also in Ps. 104 : 2b. Cf. also Jer. $10: 12 ; 51: 15 ;$ Job $2: 7$.

(iv) Cf. Is. $40: 26$ with Ps. $33: 6$; Ps. $147: 4$; Joh $9: 7$, 9; Neh. $9: 6$.

(v) With Is. $42: 5 \mathrm{~b} ; 44: 24 \mathrm{~b}$ compare Ps. 136 : 6a.

(vi) The idea of the drying out of the primeval waters and the victory over the powers of "chaos" (Is. 44:27) appear also in Ps. $7:$ : 14f; 89 : 10f; 104:6-9; Job $26: 12 f$

(vii) Is. $45: 12 \mathrm{a}$, cf. also Ps. $8: 5$ f.

The creation of man in the image of God is not mentioned by Isaiah, which is the case in Ps. 8.

(viii) Is. $45: 18$-the word tóh $\hat{u}$ is significant here and also in Job $26: 7$.

Summary.

1. The prophetical and hymnical portions of the Old Testament do not give the impression that there are direct quotations from Gen. 1 and 2. 2. Although different expressions are used in many cases there is no discrepancy as far as the general theme is concerned.

3. The repeated reference to mythological "chaos"-monsters and the poetical description of the victory of Jahwe over these monsters at creation are striking. Due allowance should be made for the poetical colouring but even then the reference cannot be interpreted in the sense that nothing of the kind happened. Cf. what is said about Gen. $1: 2$ in $\$$ IV. A.

\section{B. THE NEW TESTAMENT}

Kittel's Theologisches Wörterbuch zum Neuen Testament s.v. ktizoo gives a very valuable summary. 
As to the terminology it states that ktizein is the expression for „create" which appears most frequently, together with words which are derived therefrom. Ktizoo and its derivatives are used in the N.T. only for divine creation.

The N.'T. is clear about thit point: that God is the Creator of the worlal. Very often the expressions: ap' archés ktiseoos and apo (or pro) katabolês kosmoü are used. "Diese. Wendungen zeigen, dass die Schöpfung fiur die Welt den Aufang ihrer Existenz bedeutet, dass also mit einem vorgegehenen Stoff nicht zu rechnen ist... So liegt die Schöpfung aus dem Nichts durch das Wort den nt. lichen Aussagen ausgesprochen oder unausgesprochen zugrunde (op. cit., p. 1028). Cf. Rom. 4: 17; 2 Cor. $4: 6$.

"Everything" (ta panta) is created, cf. Acts $17: 24 ;$ Epl. 3 : 9; Col. 1 : 16; Rev. 4 : 11. „Dass hierbei jegliche Emanation ebenso wie eine vorgegebene Materie ausgeschlossen ist, ist deutlich" (ibid).

$\Lambda$. Noordtzij points out that the ,in the beginning" of John $1: 1$ is a clear reference to Gen. $1: 1$. The Word of God existed before anything else. The Word, Logos, is the effecting cause of ,all things", and this Word is God.

A salient text is further Col. $1: 15-17$. Christ is prototokos pasês tês ktiseoos, i.e. existed before everything else which owes its being to the Logos. Cf. also verse 17.

John $1: 1-3$ and Col. $1: 15-17$ both clearly indicate that creation can only be understood from the viewpoint of re-creation (restoration).

The same line of thought is found in Hebr. $1: 1-3$. Two main thoughts emerge from these verses: 1 . The selfrevelation of God reaches its acme in the Son and this Son is the mediator of creation. It is significant that it is declared that the Son made tous aionas, the ages. The Logos is also the effective cause of historical development, the centre of world history. (Noordtzij, op. cit., p. 113).

In Rev. $3: 14 \mathrm{He}$ is called, ,the beginning of the creation of God i.c. the effective cause of all things that exist".

Noordtzij concludes from this that also here creation and re-creation have their inseparable connection in the Person of Christ. (Op. cit., p. 113).

\section{HERMENEUTICAI, PROBI,EMS}

An encouraging phenomenon in present-day theological studies is the renewed interest in hermeneutical problems. Ons is inclined to regard this as somewhat belated, but in any case it is never too late. One of the vital problems is of a somewhat dogmatical character, although also in this instance Scripture's autopistia has to speak the last word. 
A. The authority of Scripture - its nature.

Every theologian of Reformed stock stands and falls by the divine authority of Scripture. Basically this is his only apriorism, because all dogma depends on the reliability of Scripture.

From the outset it is imperative therefore to be clear about the specific nature of billical revelation. In this respect recent studies have gone to the core of the matter.

The following points should be observed:

1. Scripture is not a book of revelation in the sense that in what it presents it purports to supply an answer to all questions with which life confronts us.

Mutatis mutandis the following words of H. N. Ridderbos can also be applied to the Old Testament: "The apostles as inspired heralds of the salvation in Christ did not partake of divine omniscience for the fulfilment of their task. Neither did they receive a mandate to unveil the secrets of nature, the structure of the universe, the secrets of science ....') (translated).

This is in line with what Herman Bavinck has taught: "It is generally conceded that Scripture does not use scholarly language, but that of daily experience... also when relating the story of the origin of all creatures, it remains the book of religion, of revelation, of the knowledge of (God."2) (translated).

2. Revelation does not enable its organs to be in advance of the general scientific development of their times.

A. D. R. Polman touches the essence of the matter in bis article on the authority of Scripture in Christelijke Encyclopaedie: ${ }^{3}$ ) "In order to do full justice to divine and human factors H. Bavinck speaks of organic inspiration. Inspiration is fully acknowledged, but at the same time it is confessed that it happens in this manner that the Holy Spirit takes into His service active, living human beings with their own personality and talents, with their way of thinking and acting, with their experiences, with their language and style. They are not lifted out of their time, but are used as they lived and worked, in a definite time, in an Oriental milieu, in a world with its own culture, with its own media of expression, with a limited vocabulary, with different manners and habits. The use of all kinds of literary genres which bear the stamp of their time, and have to be explained accordingly, is not excluded thereby." (translated).

3. Revelation does not correct every notion which the writers may have in connection with the structure of the universe.

This would have been imperative if Scripture purported to supply us with scientific knowledge (cf. point 1 above). The wonder of revelation 
is that it takes its organs as they are but that the product is such that it reveals what is normative for all ages, up to the end.

This brings us to the (fuestion whether the organs of revelation speak in terms of the world picture of their times or in those of popular, thenomenal language which is current in all times. The latter conception has long been the popular one in Reformed circles. The result of all my studies during recent years (in the fields of hermeneutics, exegesis, history of revelation, and cultural and historical background I have led me to the conclusion that this cannot be accepted without qualification.

It is true that phenomenal language is used (e.g. when the sun is described as the great light and the moon as the small light in (ien. 1 : 16) or when the biblical writers--just like modern man-speak of ,sunrise". This, however, does not cover all instances. Many cases can he cited where the writer speaks according to the common notions of his time, without correcting them, in any case not expressis verbis. Cf Psalm 121:6: The poet is referring evidently to the popular NearEastem notion that the moon has a somewhat similar effect as the sun (sunburn). Present-day science does not know of any physical effect from the rays of the moon. The psalmist is not concerned about these questions. His revelation amounts to this: the heliever has nothing to fear from sun or moon- whatever their alleged effects may be. It is not necessary to distort exegesis to bring the text in line with current notions.

Prof. G. Ch. Aalders has proved convincingly--according to my mind-that it is impossible to distil a coherent world picture from NearEastern writings or from the Old Testament. ${ }^{4}$, But it is impossible to escape the conviction that the Billical writers in their terminology made use of current notions. which are not corrected, but in and through the medium of this language God reveals what He wants to be revealed.

4. It is imperative to grasp what is temporary and what is perma. nent in Scriptural precepts and methods of representation.

The sacrificial laws of the Old Testament form part of the authoritave Word of God, but heing fulfilled in Christ they have no normative autho. rity for Christians.

In former days the distinction hetween auctoritas historica and anctoritas normativa was a commonplace. What follows from this distinction H. Bavinck has outlined very lucidly: this distinction makes it clear that there is a difference between the Word of God in formal and material sense. Seripture is not a law book full of articles. Revelation is an historical and organic whole. The authority of Seripture is different from that of the law of the state. ${ }^{5}$ ) 
5. Scripture elucidates man and the world, history and future, church and people from one point: the advent, death, resurrection and return of Jesus Christ. ${ }^{6}$ ) What A. Noordtzij taught long ago in his Gods Woord en der Eeuwen Getuigenis ${ }^{7}$ ) needs to be read carefully again. What he says about creation can be applied to other parts of Scripture too; viz.: All efforts to regard Gen. 1 as a true-to-nature description of the creative acts of God must be regarded as failures. They have done justice neither to Scripture, nor to the facts of nature. The main error was that exegetes viewed Gen. I by itself and had no insight in the meaning of the Holy Spirit through the whole of Scripture I underscoring by me). They forget that Holy Scripture has its own view on the cosmic process and always connects it intimately with the great spiritual struggle which dominates the history of the world. The selfrevelation of God has its culmination point in the incarnation of the Word. Holy Scripture speaks of creation only hecause it wants to speak alout the mighty fact of re-creation. God does not meet our inquisitiveness and does not want to save us further study. ${ }^{8}$ ) The central idea of Scripture is: the kingdom of God. 1On the question whether this implies that Scripture does not reveal anything in connection with nature and creation cf. IV.

The otherwise exquisite booklet of Karl Cramer: Genesis 1-11: Urgeschichten?, Tübingen, 1959, does not take cognizance of this fact.

\section{B. THE RôLE OF SCHOLARSHIP IN THE EXEGESIS}

\section{OF SCRIPTURE}

\section{Should philosophy play any rôle in exegesis?}

The history of exegesis is full of examples of its distortion hy philosophy. As instances can he quoted: Philo, Origen, the Scholastics. Also in modern times there are striking examples. When the writers adhere 10 exegesis proper one can in many cases sulsscribe to their views. But as soon as philosophical speculation looks round the corner, the exegete puts his question-mark.

It has become a commonplace in Reformed circles that there is no such thing as "Voraussetzungslose Wissenschaft". From this it is concluded that exegesis also cannot do without some apriorisms, and that these should be derived from philosophy, preferahly from Christian philosophy.

If one thing emerges, however, out of present-day studies, it is that exegesis basically means: read, read, listen, listen, till the end: read and listen.' This implies that the exegete should not open a discussion with the text and that his own ideas as well as that of contemporary philosophy are irrelevant. If anything is necessary from our side, cer- 
tainly not philosophy, but a study of the original languages of Scripture, together with the cultural and historical background, canonical problems, the history of revelation. all of which disciplines centre round the Scriptures. Last not least, the prayer of the believing spirit is indispensable.

Philosophy brings with it the danger of trying to interpret Scripture according to our categories of thought. And these are of Western origin, so that even if we speak of a Christian philosophy it may be that attention has been paid to current exegesis, but the formulation of philosophy is in our concepts.

It is true that not orly what is stated explicitly is revelation of God, but also that which follows according to the general logic of mankind. But I agree with Vriezen when he warns against subjectivism in this respect, ${ }^{2}$ ) so that also in this case it is better to listen to the analogia Sacrae Sicriplurae than to one's own logic, which may be false. ${ }^{3}$ )

Much harm has been done to exegesis by the fact that-consciously of unconsciously---Scripture was Westernized. The exegete is then led by Western categories and reads Scripture as if it originated somewhere in the Westem world during the 20th century. I am therefore in full agreement with Miskotte when he declares: "Die Theologie als solche besitzt keinen eigenen spekulativen Erkenntnisweg; sie ist gebunden an die Texte. sie lebt von Exegese..." The doctrina prophetarum et apostolorum. should be distinguished from all other voices in the world. Miskotte continues: Die erste hermeneutische Regel ist daher diese: Nichts kann recht verstanden werden, wenn wir nicht die Worte, Bilder, Gedanken, Wendungen hören aus diesem bestimmten Raum, dieser Sphäre, diesem I.cbensganzen im Sprachganzen, in ihnen und auf sie hin. Hermeneutik. angewandt auf eine Schriftstelle, muss der Schrift entlehnt sein, muss aus dem Bereich ihres Lebens, ihres Lichtes, ihrer sonderlichen Wabrheit hervorgehen." ${ }^{4}$,

2. Should the special sciences (,vakwetenskappe") play a part in exegesis?

In this paragraph we are considering the results of scholarship) taken in its widest connotation, including physical science, but not commensurate with it. And what concerns us here is fact, not theory. As soon as we come to theorizing, philosophy comes in again and perhaps also a distorted exegesis. I realise that it is very difficult to distinguish between fact and theory, but there are cases in which this is possible. In this respect I differ from J. Ridderbos when he states that people of the Reformed confession do not accept anything that presents itself as science but only that science that has its startingpoint in the acknowledgment of the Word of God.5) I should think that facts are facts, ly whichever science they are discovered. It is only the biassed man who can 
exclaim that there is no such thing as a kangaroo, when he sees one in the zoo.

Otherwise I agree with Ridderbos when he says: For the correct interpretation of Scripture science is of the greatest importance. We should realise the possibility that certain results of exegesis may be proved false as a result of investigation. A sinful conservatism may not deprive us of the light that God wants to shed in the way of his Providence. An injustice may be done to science in an appeal to Scripture to substantiate an opinion that in reality does not rest on Scripture but on human insight into it. A classical example is the tenacity with which the Roman church opposed the Copernican world view. ${ }^{6}$ )

The position is this: scientific research in fields of science may never be a binding criterium for exegesis, hut always an inducement to a testing of prevalent exegesis. But in final instance Scripture itself has the verdict. ${ }^{7}$ )

In the revelation in connection with creation this is of special importance. In how far have biology, geology, palaeontology something to contribute in the exegesis of, say, Gen. 1 , in so far as these disciplines purport to teach something about the age of the earth and its creatures.

It is possible to sin in this respect per excessum and per defectum. For some theologians physical science is of such paramount importance that what Seripture teaches is rejected with a shrug of the shoulders. Others have very little respect for what physical science has to say and they simply ignore it.

The question becomes urgent when sincere, Bible-believing Christian scholars tell us that much is still the field of speculation, but that the different sciences all lead to the conclusion that long ages of history have elapsed between the appearance of inorganic matter and present-day man. This immediately leads to the exegesis of the word jom (day) in Gen. 1. And if scientists tell us that catastrophes and death in the animal world occurred long before man appeared on carth, the question is immediately raised: but is death not the result of the sin of man? Bavinck has already stated in his Dogmatiek that geological and palaeontological researches may serve a better understanding of the story of creation "From the facts, brought to light hy geology and paleontology, Scripture and theology have nothing to fear."8)

The following words of Ramm deceive consideration. Does not the most hyperorthodox amongst us realize that most of the views he now holds about the Bible, medicine, science, and progress which he thinks are so orthodox, safe, sane and Biblical, would, a few centuries ago, have cost him his life?" ) Bavinck remains an example also in this respect. "It is the lasting merit of Bavinck that he did not go out of the way tor dodge the confrontation with modern science and its results, but 
tackled the problems with an open mind and honestly. Although he did not do this consistently on all points, he always tried to give their due to Scripture as well as the results of science." (Bremmer).10,

(translated).

\section{QUESTIONS PERTAINING TO THE REVELATION IN CONNEC.TION WITH CREATION.}

1. Christ has a noëtical as well as an ontical connection with creation.

By the first is meant that knowledge of Christ is necessary for grasping the meaning of the chapters dealing with creation. It is a defect in Reformed theology that this has not received the attention it deserves. In any other case we regard it as axiomatic that the Old Testament can only be understood in its true sense when the New Testament fulfilment is also taken into consideration. But it seems as if in the case of creation a complete cosmology has been worked out by theologians, without taking into consideration this connection with Christ. It is clear that in our exegesis of the Old Testament texts that refer to creation we have always to keep in mind those of the New Testament. (Cf. \& I. B.).

This implies also that the account of creation in its full revelatory sense can only be grasped when re-creation is also taken into consideration. Both are the result of the same divine Word. C. Coll. 1 : 15-17; Hebrews 1 : $1-3$; Rev. $3: 14$. It is very significant that in the Old 'lestament creation is mentioned preferably when the aim is to invigorate faith in the almighty and saving acts of God (cf. 2 Kings 19: 15; Is. 4) : 12--21; $42: 5 ; .51: 13$; Psalm 24;89:12).')

If we state that Christ has also ontical connection with creation, this means that he has not only soteriological significance in this connection, but also cosmological. He is not only mediator of re-creation, but as Logos also of creation. ${ }^{2}$ )

Similarly, Brunner says on this point:

"Das Schöpfungszeugnis an dem wir uns primär zu oriëntieren hahen, steht nicht in Gen. l, sondern in Joh. 1 und an einigen anderen Stellen des Neuen T'estaments." He draws a parallel between the story of creation and the Messianic prophecies. "Das in die Geschichte vom Sechstagewerk gekleidete Zeugnis bleibt ein machtvoller und ewig rindrucksvoller Ausdruck vorlaufend-alttestamentlicher Selbstkundgebung Gottes; die massgebende Gestalt der Selbstoffenharung des Schöpfers ist Sie ebensowenig als Jesaja 9 die massgebliche Gestalt des Christuszeugnisses it". He adds: "Damit soll keineswegs die bleibende Bedeutung und die unentbehrlichkeit des alttestamentlichen Zeugnisses von der Schöpfung - nicht nur von Genesis I und II, sondern ebenso sehr der 
Propheten, der Psalmen und Hiohs - geleugnet sein. Zur Ergänzung, zur Füllung der knappen neutestamentlichen Aussagen kann nicht genug auf die gewaltigen und reichen Zeugnisse des Nlten Bundes geachtet werden..."4 I can agrec with the general trend of his remarks, but his example is not very well selected. The Messiah in the Old Testament remains a promise, whereas creation is a fact that was completed when the seventh day was reached.

2. The accounts of creation provide proto-logy in the same way as the prophecies and apocalyptics have to do with eschato-logy.

This is very often forgotten. If, for instance, it is stated by the Reformed Ecumenical Synod $(1949$, cf. $\$$ V. infra) that the historical character of the revelation in Gen. 1 and 2 should be maintained in its full sense, it would be a logical conclusion that we have here history in the same sense as when it is stated that David brought the ark of the convenant to Jerusalem. Directly following the above statement follows a second which qualifies the first: the true, absolutely reliable description by God of His creation is given us in a form intelligible to human heings, so that it is no adequate rendering of this divine deed, but sufficient to know and honour Him as our Creator and Lord.

It should be remembered that no human being was present during by far the greater part of the creative work of God and that our language can only as if in stammering give expression to the mighty deeds of God.

It is significant that the Hebrews included the historical hooks of Joshua, Judges, Samuel and Kings in the collection of the prophets and called them the nebîm rîsónim (earlier prophets). Edward Young says that they comprise "an interpretative history of God's dealings with the theocratic nation from the entrance into Canaän until the dissolution of the theocracy in the exile".5) Can the same not be said of the Pentateuch, especially if it is kept in mind that Moses was one of the greatest prophets (cf. Deut. 18 : 18)?

We have to envisage then a prophet for prophets) standing on the platform of their times and turning the face alternately to the past and to the future, and in each case prophesying about the kingdom of God. J. Ridderbos touches this point in his brochure: Het Verloren Paradijs: "With respect to creation we have to do with something which has preceded human history. The whole record thereof must therefore rest on special divine revelation and by virtue of this it approaches far more to the character of prophecy. Now it is not too miraculous for God to describe the way in which creation took place in detail by means of such a special revelation, but there is reason to reckon at least with the possibility that in the exegesis recourse will also have to be taken to the rules that pertain to the explanation of propletical writings. There 
are, moreover, in the story itself elements which indicate that we should he on our guard a too literal interpretation".6) (translated).

If this is the case we have to keep in mind the possibility that. as in the case of predictive prophecy, it is progressively difficult to explain the facts that recede in the hackground of the primeval past, because the contours become fainter.

Accorling to G. (.h. Nalders the mighty creative deeds of God are communicated to us in anthropomorphic way and on our part astonishment is more fitting than inquisitive intrusion. I quote from: De exegese van Gen. 2 en 3 en de beslissing van die synode van Assen, Kampen, (year of publication not mentioned. hut about 1926): "Creation is a fact so basically different from the history of the world which we experience, so totally different and so unique, that God could not speak in terms which would be remotely adequate to this unique deed, without it becoming absolutely unintelligible to us... What in the case of the story of paradise and fall pertains to a single instance is with regard to Gen. 1 applicable to the whole chapter (underscoring by me)". It follows from this thesis that to state apodictically that this, and nothing else, is the meaning of an expression used in connection with creation, is scientifically unwarranted.

The revelation in comnection with creation presents an account of what happened in reality, hut this account comes to us in kerugmatic style. Therefore: no mythology, or saga or cadre, or poetry, at least in Gen. 1 and 2.

\section{IS THE CURIRENT VIEW STILL. TENABI.E?}

1. What do we mean by "the current view"?

We have in mind here especially the views of Reformed scholars who via Calvin inherited this view from some of the church fathers.

In his Institutes (I, 14, 20) Calvin refers those who wish to know more about creation to Basilius and Ambrose, both church fathers of the fourth century A.D. Both these fathers, however, are guilty of the same error as some exponents of our century, namely that they do not hesitate to combine the views of their own times with the data of Scripture. Niehoer even detects the influence of the allegorical method of Philo.') H. Bavinck says: All the works on the hexaemeron from the church fathers to the 17th century have their stand on the aristotelian. ptolemaic world view and this world view naturally influenced the exegesis of the hexaemeron. ${ }^{2}$ ) 
Although the names of hoth Basilius and Ambrose are mentioned it is sufficient to consider Basilius, hecause Ambrose leaned heavily on him. The work of Basilius called Hexaemeron attributed very much to his fame and held the field for many ages. He was extremely well versed in philosophy and natural history.

He stressed the literal sense of a text in reaction to the allegorizing o! Origen and regards the days as natural days. But he says nothing of the seventh day. In connection with Gen. I : I he taught that "heaven and earth" are "as it were the foundations and hases" and therefore have to be created first. In the earth were water, fire and air-all mixed up.

Basilius was convinced that the earth was covered with water and argued on the ground of the LXX, which reads that the earth was invisible and not ordered. This invisibility he attributes to the waters that covered the earth. In reply to a question why the earth was invisible, it being possible to see the ground through water, he says that this is caused by the fact that the "upper heaven," which was created first with its more opaque substance, shut off the heavenly light from the earth. That is the reason why everything on earth was enveloped in darkness.

Nieboer comes to the conclusion that Basilius reads Gen. I as if it was written by a Greek philosopher. In the Greek concept of "substance" a great danger was inherent, hecause it contained the idea of autonomy, being gifted with certain potencies. When once matter was created the course of history was determined. As Creator God did nothing more and matter maintained itself. Nieboer sees some relationship hetween the current view and the thoughts of Basilius. ${ }^{3} 3$

In more recent times even scholars of the stature of Bavinck and Kuyper evidently could not escape the lure of philosophy in their dog. matical work.

In his dissertation: Herman Bavinck als logmaticus R. H. Bremmer points out that the platonic doctrine of ideas can be detected in the exposition by Bavinck of the doctrine of creation. In creation God places the ideas which He conceived in his eternal counsel. In connection with this doctrine of ideas Bavinck puts Christ in the centre in the doctrine of creation, with reference to a series of biblical texts in which Col. I figures prominently. In the Logos God has crystallized his ideas a- it were. In creation these ideas are concretisized because the Son is mediator of creation. Again the relationship of Bavinck to the christianized Platonism of St. Augustine plays a rôle. ${ }^{4}$ )

With respect to Abraham Kuyper A. D. R. Polman says in Christelijke Encyclopaedie ${ }^{2}$ ) (s.v. Kuyper) that this giant among theologians is not read any more by the Dutch people (which is still the case with Bavinck). 
As one of the reasons for this fact Polman mentions the indebtedness of Kuyper to the Reformed theologians of the years 1619 to 1750 , who were strongly influenced by the scholastic method. It would have been better-thus Polman-if Kuyper had followed Calvin more closely, because this prince among theologians has a lasting place in his truly reformed design and the ecumenical character of his theology.

The strongest exponent of the current view during the 20th century was Prof. G. Ch. Aalders, especially in his voluminous work: De Goddeliike Openbaring in de drie eerste hoofdstukken van Genesis.

Nieboer summarizes the current view as follows:

a. The expression: "heaven and earth" of Gen. 1 : 1 means: the universe according to its substance. This verse says then that God first created the matter, the stuff of heaven and earth.

b. Gen. I : 2 depicts the condition of the earth as it was after this first creation and relates of this condition the following:

1. the earth (in an article in Chr. Encyclopaedie, first impression, s.v. Schepping, Aalders speaks of the "globe of the earth") was surrounded by water (in any case with dampness) and enveloped in darkness;

2. the Spirit of God in this period prepared the work of the six days;

3. then comes the hexaemeron in chronological order.

4. on the seventh day God rested. There is difference of opinion concerning the length of this day. Some regard it as a natural day while others hold that the day had a morning but not an evening which means that it is still continuing.

2. Why is the current view regarded as untenable?

In general it can be said that it viewed the biblical revelation in connection with creation too onesidedly through Western eyes and from a preconceived theory.

This is combined with some definite trends of thought:

(i) Fundamentalism.

In Christelijke Encyclopaedie (1958) s.v. Prof. Ned B. Stonehouse gives the following description of fundamentalism: The term applies to a typically American religious viewpoint. The origin of the term must be looked for in a series of pamphlets which appeared in 1910 and were called The Fundamentals. The movement directed its attention and defence to the fundamental principles of the Christian faith which they regarded as endangered by the attacks of liberalism and modernism.

On account of certain accents and peculiarities it cannot be regarded as synonimous with orthodoxy, hecause sometimes certain details were stressed which have to be distinguished herefrom. Certain facts of the history of salvation and certain dogmas were selected at random as 
being something extraordinary. For this reason Fundamentalism is also characterized as Biblicism and it is significant that skeletonlike formulations of doctrine were given instead of the historical confessions.

The fundamentalists take a very secluded position against those who do not subscribe to their principles. They are uncritically straightlined in their conceptions and simplify the problems in connection with faith and science. Thus far Stonehouse.

Lever describes as fundamentalism also the assumption that Genesis contains not only revelation about creation and salvation but also scientific, exact knowledge. The truth of scientific data has to be controlled by scriptural data. This implies that Genesis is written in scientific terms, namely in such a form as they were formulated some centuries ago. A clear example is the exegesis of the word "kind", which was understood as meaning that God created the recent hiological "species", a name which rests on a concept that is about 250 years old. "A great deal of the unpleasant controversy round evolutionism was caused by the error in fundamentalist thinking. For when "kind" is not equal to "species", a change in species can he accepted calmly without one's belief heing endangered ly it." Fundamentalism has its origin in an important measure in an interpretation of Genesis with the aid of natural science of a few centuries ago. The next step is that the interpretation found in this way is made normative for natural science of today. The dangerous kernel of fundamentalism is this: it regards the truth of faith as scientifically demonstrable, by which procedurc helief and intellect on the one side, revelation and science on the other side come to lie on completely the same level. The consequence is at reasoned belief and a false science, with as honest consequences doubt and unbelief. ${ }^{5}$ )

\section{(ii) Supranaturalism.}

This theory has to do with the idea that a miracle is some extraordinary deed of God by which He intervenes at specific points of time to break through the laws of nature and to create something new. Diemer (cited by Lever, op. cit. p. 177), was of the opinion that this supranaturalistic view has its origin in the handling of the biblical miracles with the aid of the thought apparatus of a non-Christian philosophy.

Kuyper was in agreement with supranaturalism in so far as it holds that God is transcendent above nature (versus pantheism). But his objection was that supranaturalism seems to teach that nature, with all its powers and laws, is autonomous next to, under and over against God. The error of supranaturalism is overcome only when every thought of an autonomous and permanent existence of nature is extirpated root 
and branches, with the conviction that both nature and all its powers and laws are nothing in themselves, but are from moment to moment what they are through the decree of God. They are all His servants ( $E$ voto Dordraceno I, 239).

Kuyper is opposed to the idea that God intervenes merely incidentally, because nothing moves without the power of God. In the eyes of God there is ne miracle.

It is the conviction of some scholars that this supranaturalism has also played a part in developing the current view, according to which the work of each new day was an intervention by God in the course of nature. Over against this scholars like Diemer and Lever place the idea of a "general evolution" under the providence of God. According to this view there was only one creative act (viz. in the beginning). The work of the six days belongs to the providence of God.6) (For our own view on this problem, cf. $\$$ IV.).

Also in another sense supranaturalism has played a part in the current view. Supranaturalism accepted a supernatural revelation, but taught that this revelation must be vindicated by reason, which implies that revelation cannot be in conflict with it. Honig (in Christelijke Encyclopaedie first edition, 1929) says that the main error of supranaturalism was that it did not take into consideration that our reason is darkened ly $\sin$.

Although Reformed theologians are far removed from supranatu. ralism, the question must be asked in all sincerity whether even they did not forget this truth sometimes when they tried to "vindicate" the truth of Scripture against evolutionary theories. The right way evidently is to apply sound exegetical principles. to he aware of what science teaches, and to testify where necessary, without trying to be an advocate for the cause of God.

If we summarize the history of the current view it is clear that pagan philosophy as well as "Christian" scholasticism played their parts, together with concepts from the philosophy of nature deriving from former centuries. For these reasons a new way has to be looked for, which is my humble but earnest endeavour in the following pages.

\section{AN ATTEMPT AT A NEW APPROACH}

A. Gen. $l: l, 2$.

These verses arc of paramount importance for the exegesis of the rest of the chapter and each word carries weight. From the outset it 
must be stated that Gen. 1 : 1, 2 presents the most difficult "cruces" of the whole Bible.' )

Gen. $1: 1$.

Is this verse a complete sentence or a temporal clause subordinated to verse 3 ? On the basis of grammar only both translations are permissible. In the first case berêsjit must be taken as absolute; in the second case as construct. In the second case there is no creatio ex nihilo, but a pre-existent "chaos" must be presupposed. But even when the first alternative is preferred and verse 1 regarded as a complete and independent sentence, verse 2 still presents an enigma. Where does the tóh $\hat{u}$ uabóhu-condition come from? It is clear that the Old Testament rejects a dualistic conception throughout. One can agree with Childs when he declares: "The situation seems a most perplexing one." 2 )

If the first verse is a complete sentence, is it just a superscription giving a general description of that which is about to follow, or is it a separate act of God, a creatio prima, which has as result "formless matter"? And is verse 2 the description of this formless matter? Does hašsúmajîm and hä ärès denote formless matter or are these words the Hebrew term for the universe as we know it?

berésît.

If the word is taken as a construct: In the beginning of God's creating heaven and earth---the earth was waste and void etc., it implies that God started from primordial matter. In his penetrating exegesis of Gen. $1^{3}$ ) N. H. Ridderlos concludes that rêšs temporal meaning (cf. Is. $46: 10$ ) and that the word can also denote a beginning in absolute sense (cf. Prov. $8: 22$ and Sirach $15: 14$ ), so that there is no ground for the translation as if the word denotes a beginning after something had existed already.

barä:

N. H. Ridderbos agrees with Buhl (in Festschrift - Kittel, 1913) that fundamental in the word is: 1 . the idea of newness and exceptionality; 2. the idea that God works "mühelos" (without exertion). It denotes an act requiring divine power and is never joined to an accusative of the material.

Although it is true that the word is not used always for creatio ex nihilo, it is very significant that in Is. 40f. the coming salvation is regarded as a new creation. If berếsît is taken as construct and verse 1 is connected with verse 3 , one would be inclined to sec in bárä something similar-out of "chaos" comes a "cosmos". But if berêsit is taken as absolute there is no suggestion of something hefore the creative act, so that in this case a creatio ex nihilo, or rather a creatio post 
nihilum, must be understood.

'èt hašsimajîm we'èt hẩàrs.

N. H. Ridderbos concludes: "Dieser Ausdruck deutet alles erschaffene in als das Weltall". ${ }^{4}$ ) Nieboer is of the same opinion: heaven and earth - the world. Everything that manifests itself against the heavens above and on the earth beneath were created by God-nothing excepted, even those things that are not mentioned in the description of the work of the six days. ${ }^{5}$ )

If this is the case the words "heaven and earth" do not denote "unformed matter" and the idea of creatio prima must be discarded. The following conclusion is that berêt sit cannot be pressed to mean a certain definite point in the dim past, because only on the seventh day the heavens and the earth were completed. This is the idea of Sven Herner: ${ }^{6)}$ "Mit der Schöpfung begann die Zeit. Die Schöpfung geschah, ,im Anfang'. Da indessen Himmel und Erde ,im Anfang' erschaffen werden, bezeichnet diese Zeithestimmung nicht nur der erste Schöpfungsakt, sondern die ganze Zeit, während welcher die Schöpfung vollbracht "urde, also die ganze Schöpfungswoche". This implies that if the millions o' years of geology are true the word berêsît covers this whole period. The best solution will probably be: in the beginning God started with the work of creation which ultimately resulted in the universe which we now perceive. (Cf. Edward J. Young in Westminster Theological Journal, Nay 1959, p. 146: " $\ldots$ the first verse serves as a broad, comprehensive statement of the fact of creation").

Gen. $1: 2$.

Attention is now devoted to the earth only. It strikes one how naturally the transition from verse 1 is made. Viewed superficially the conclusion could be drawn that the condition of the earth as here described follows immediately on what is mentioned in verse 1. Detailed exegesis, however, presents us with many problems.

The main problems are these: Is the connotation of the words used here the same as in the rest of, the Old Testament? Do we find in verse two the description of just an incomplete earth or do the terms that are used denote something that is "unheimisch"? If the latter, where does this come from?

tóh ư wabóhầ:

I agree with N. H. Ridderhos that etymology is of no avail here. ${ }^{7}$ ) The lexicon of Koehler-Baumgartner gives as the meaning of tóh $\hat{u}$ : das Leere. N. H. Ridderbos admits that the fundamental meaning of the word (which occurs 19 times in the Old Testament) is: das Leere (the void), das Nichtige (nothingness), but warns that these terms have a much more ominous meaning for the Israelites than for us. tóh û 
can denote the desert, especially in its terrifying aspect (cl. Deut. 32 : 10; Ps. $107: 40$; Job $6: 18 ; 12: 24$ ) but also idols and their worshippers 11 Sam. $12: 21$; Is. $41: 29 ; 44: 9$ ). Especially significant is Jer. 4 : 23-"cosmos" becomes "chaos" as a result of the judgment of God on sin. This verse shows that tóhâ and bóh used conjointly also convey the idea of something terrifying. The same applies to [s. 34: 11 where there is reference to a future judgment also. ${ }^{8}$ )

hóšèk.

In the Old Testament darkness is also a situation of "Bedrohung und Gefahr". According to Is. $45: 7$ hosè building of God, so that from the outset it must be stated that dualism is cut at the roots. In any case darkness has a certain inferiority as compared with light. Night is the time of the wicked. The powers of evil reign during the night, whereas the morning is the time of God (Ps. $46: 31 ., 6 ; 90: 14)$. The answer to prayer is expected in the morning (Ps. $88: 14$, cf. Ps. $130: 6$ ). In the promised future the night will disappear (Is. 60 : 19f.). The day of the Lord (jôm Jahwe') will be darkness and no light (Am. $5: 18$, cf. $8: 9)$. se'ól is a land of darkness (Ps. $49: 20$ ). In Jer. $4: 23$ hósèek occurs in the same verse as tóhî wábóhâ. The ocean, or at least parts thereof, is often described as a place of darkness. The same is the case with the desert. It is significant that it is not said directly that God created the darkness and that it is not called "good".

tehôm.

Several writers see some connection between the waters in the same verse and tehôm.

The primeval flood (or the sea) is often mentioned together with monsters: leviathan, rahab, the dragon etc. The Hebrew words can denote ordinary animals (cf. Job $40: 25$ ). But often some phantastic entity is meant. Almost without exception these monsters are used to denote enemies of God and His people (Job 9 : 13; Ps. 68 : 31; 74 : 13f.; 89 : $10 f$; Is. $27: 1)$. With a few exceptions these monsters are always ocean monsters. Also the flood is an enemy of God (Ps. $18: 16 ; 104: 7 \mathrm{f}$; Is. 17 : 12; Ps. 65 : 8; Dan. 7 : 2).

In some portions of Scripture we find the idea that in primeval times this flood (= power of "chaos") was prevalent. But Jahwe has vanquished it (cf. Job $9: 13$ ). J. H. Scheepers comes to the conclusion that in some portions of Scripture we find traces of a conception according to which the flood at creation was a personified power of "chaos" which was vanquished. He acknowledges that most of the relevant texts use poetical language. But the mythical presentation and language 
are used to serve their own views. They do not subscribe to the contents of the mythical conceptions. Scheepers concludes that they see and describe the ocean as a dangerous force, a power of "chaos" which was confronted by Jahwe at creation and was changed by Him in such a way that life hecame possible. The ocean is not destroyed but kept within bounds, cf. Ps. I04 : I0f. But even after this it forms a continuous threat, of. the deluge history and Ps. $46: 31 ; 89: 10$; Prov. $8: 29 .^{9}$, werûuh 'elihhìm merahèfèt 'al penê hammajîm.

Childs calls this an extremely difficult passage. Fortunately the verb merahiefet does no longer present the difficulties it formerly did. The meaning of the Helrew root of $r h f$ is uncertain. In Arabic an infrequent verb occurs, but with the meaning 'to be soft'. There is an obvious connection with the Hebrew in the Syriac where the root signifies to 'Ioster', 'hover' or 'brood'. The Ugaritic offers the closest parallel, where Gordon finds the meaning 'soar'. Deut. 32 : 11 makes it clear that the meaning can never be "hatch". Köhler renders the word in Gen. $1: 2$ as 'hover trembling'. Childs is of the opinion that it can best be rendered by some verb as "hover", "flutter", or "flap". ${ }^{10}$ )

J. H. Scheepers quotes Peters according to whom the verb every. where describes "violent, not gentle motion" and who pleads for the meaning "rushing upon". The qittél is taken as iterative.

Against the opinions that the rual has a fertilizing effect the following is noted by Scheepers:

a. It is strange for the rûah to affect the power of "chaos" in this way. The verses following immediately have no connection with it and nowhere is there any text in which this is the case.

b. Nowhere else in the Old Testament is the rûnh 'elóhim described as a principle of life in cosmic sense.

c. There is no indication that rûah is regarded here as an independent personal Being. ${ }^{\prime \prime}$ )

The words rûah 'elóhim may be translated: "wind of God" or "Spirit of God". Some scholars take the term "elóhim" as an indication of the superlative. There are instances in which the divine name is used in this sense. Here the meaning would then be: a tempestuous wind. I agree with Childs that the question at issue is whether this is the likely interpretation of Gen. 1 : 2. "Of the many occurrences of the phrase riuah 'elókim, no single instance in the rest of the Old Testament can be brought to hear where this interpretation is warranted. The attempt, therefore, to eliminate from verse 2 all positive relationship with verse l cannot be carried through."12)

Scheepers favours an exegesis which takes rîah as denoting "wind". 
Here a wind which makes life on earth impossible. In his opinion this fits in well with the rest of verse 2. Elsewhere in the Old Testament winds are described as the powers that threaten life on the seas (Ezek. 27 : 26; Jonah $1: 4$; Ps. 48 : 8; 107 : 25; J)an. 7 : 2; Cf. also Matth. $8: 24,261$. In Gen. $1: 2$ Scheepers sees in the wind of God the power wilh which He battles against the waters as power of "chaos". Gen. $1: 2$ is then a prelude to the work of the six days where God makes cosmos possible hy fixing boundaries over which the powers of "chaos" are not allowed to come. A strong argument in favour of this is that throughout the whole chapter the name 'elohim is connected with creating, ordering, and not with "chaos".

N. H. Ridderbos is in favour of this also, but wants to translate it a" "breath of God". In this case the exegete must choose between two possibilities: must we think of a wind sent hy God or of a power of God which generates life or life-germs? Ridderbos is in favour of the first alternative for the following reason:

In the O.T. life-generating activity is often attributed to the rûah 'elóhim (cf. Ps. 33 : 6; 104 : 24f.), but never in the same sense as here.

What function is attributed to the riah 'elohim? Some think of the drying out of the earth, which inplies that there is a battle with the waters (cf. Gen. $6: 1$; Ex. $15: 8,10$ etc.). H. G. May suggests that the wind sweeps the air and combats with darkness in that the air is swept clean of dark clouds. Aalen objects to this view because that would mean that verse 2 anticipates verse 3 where the creation of light is narrated. ${ }^{13}$ ) According to Aalen verse 3 gives the impression that the creation of light was totally unprepared, and happens solely on the Word of God. To my mind the exegesis of May is not precluded by verse 3 . It may be that there was some preparatory work, but this does in no way exclude the absolute necessity of the creative word.

N. H. Ridderbos suggests that we may even think of combining the "breath of God" with the "speaking of God", cf. Ps. 33 : 6; Is. 11 : 4; Ps. 147 : 18. At first the breath of God moves over the waters-bridling them in their force. Then the breath of God becomes a speech and at the word of God the darkness has to flee and the waters go to their allotted place.

The function of verse 2.

The cardinal question to which a reply must be given here is: how did the uriter of Gen. 1 figure the condition of the earth before the sin of man?

N. H. Ridderbos says: "Für ihn war die Welt, bevor der Mensch 
in Sünden gefallen war, keine Idylle". ${ }^{4}$ ) He continues: Although everylhing is "very good" in the eyes of God (Gen. $1: 31$ ) at the end of creation, this detracts nothing from the fact that once upon a time, before the sin of man, there was a condition, in which the forces which made life impossihle reigned without any limitation. And when the anger of the lord is kindled He unbridles them again (Gen. $7: 11$; Ps. $46: 3 f ; 3: 3$; Joh 38 : 8 f.).

The main issue here is the following (and to my mind $\mathrm{N}$. $\mathrm{H}$. Ridderbos does not tackle this problem squarely): It is not clear whether the "life impeding elements" (levensbelemmerende factoren) which Ridderbos sees in verse two are the result of the fact that we have to do with a preliminary phase (call it creatio prima if you want it that way), that is to say that the condition of tóhâ wábóhâ etc. is neutral, or whether there is something evil contained in it. And if so, did God create that evil or is it the consequence of some or other debacle before the fall of man? (Or is evil from eternity, independent of God?

This question is also intimately connected with the problem with which the natural sciences confront us. According to these disciplines catastrophes took place and death occurred in the animal world long hefore man made his appearance. Is death in the animal world something normal? $\mathrm{Or}_{\mathrm{r}}$ is it the consequence of some disruption or curse? So much is clear that if death occured in the animal world before the appearance of man, it has no connection with the sin of man.

The so-called restitution theory connects Gen. $1: 2$ with the fall of angels and especially of him who is called the prince of this world, Satan. If this theory is accepted the work of the six days is a restitution, the creation of a "cosmos" out of a "chaos" (cf. what is said later on in connection with the work of the first three days).

This theory is worked out extensively by Sauer in his Vom Adel des Menschen. ${ }^{15}$ )

He speaks of "der eigentliche Ur-Störung" and sees the geological periods as covering the work of the six days. In these then we not only have the progressive work of God but also, by permission of God, the demoniac work which explains "Bastardbildungen, Schreckenstiere, gegenseitiges Morden, Krankheit und Tod in jener urzeitligen Lebewelt".

'This implies that when man is placed in paradise animals outside of paradise are carnivorous. Sauer cites (evidently with approval) Keerl who says: "Wenn die Erde eine Stätte des Lel,ens gewesen wäre, so hatte es keines Paradieses bedürft... der erstgeschaffene Mensch stand seiner Anlage und Bestimmung nach hoch über der Erde, war... dem Gesetz des Todes ursprünglich nicht unterworfen, und darum hat Gott für ihn das Paradies gepflantzt, wo ... der Finsternis - und Todesbann 
der Erde überwunden und aufgehoben war... Die Pflanzung des Paradieses ist somit, vom biblischen Standpunkt aus betrachtet, ein unwiderlegbares Zeugnis für den Finsternis - und Todescharakter der (ausserparadiesischen) Erde".

Man was commissioned to expand his dominion from paradise over the whole earth which should lead ultimately to the liberation of the animal world. As man failed in his charge destruction remained in the animal world, on mans account. If creation groans even now it is because of man. For this reason the liberation of creation can take place only with the liberation of man (Rom. $8: 21$ ).

The curse on the soil which was cultivated by man (Gen. $3: 17--19$ ) does not mean that then for the first time the whole world of animals and plants came under the reign of death. With the exception of the snake nothing is said here about the animal world and the curse on the soil is accurately defined: it will produce thorns and thistles. It is unnecessary to go further than this. It should be noted that the curse does not imply that thorns and thistles are created now. Man is the last creature. Thorns and thistles intrude into the world of man from the outside. Scripture does not warrant the conclusion that the $\sin$ of man had as its consequence "eine allgemein verheerende -- bei den Tieren geradezu anatomisch--physiologischen-Umbildung der gesamten Naturwelt".

Nevertheless, man is guilty of the present suffering in nature, because he as king does not execute his kingly office. Only when he is saved finally, the liberation of the creature can take place.

With respect to Rom. 8 : 20 Sauer holds that the Greek dia with accusative has to be translated "by" (durch). He compares Rev. 4: 11; $12: 11 ; 13: 14$ and quotes the commentary of Lietzmann on Romans, which cites examples from the Greek papyri. Creation is subjected to vanity by One who subjects, i.e. God. Sauer connects the great judgment of God with the great cosmic revolution caused by Satan.

Usually this exegesis is summarily rejected. Ramm says that this theory arose when theologians became convinced that the flood in the days of Noah could not provide an explanation for the geological data. As the surface of the earth was studied and deciphered it became clear that a flood of one year's duration could not account for the phenomena of the rocks. What the geologists needed was time. Then the idea was launched that the time element could be found in Gen. $1: 2$. During the tóhâ-wábóhû-period all geological phenomena could have taken place. Nobody knows how long this period lasted. ${ }^{16}$ )

One notices here the strange phenomenon that this theory was sponsored by Fundamentalism for a long time, but that it was first 
put forward by the rationalist Rosenmüller in 1776. Before that the Remonstrant professor Episcopius (†1643) advocated it. Later on theosophists accepted the idea with the addition that the first world was the habitation of angels and was destroyed in a catastrophic way through their (all. ${ }^{17}$ )

It is not necessary to give a detailed account of the objections which in the course of time have been launched against this theory. I may refer to the work of Ramm. ${ }^{18}$ ) Noordtzij's criticism reads as follows: Gen. I does not give the impression that repeated acts of creation are meant. Furthermore, nowhere in Scripture primeval heavenly lights, waters, lands and plants are mentioned. Finally, geology does not accept an all devastating catastrophy or a series of such catastrophes as required by the restitution theory. ${ }^{19}$ )

Berkouwer in his recent work on " $\sin " 20$ ) says that the restitution theory as an interpretation of Gen. $1: 2$ is abandoned practically by all, because it is purely speculative and has no ground in the creation narrative. He refers also to Von Rad who terms this theory as "diese gewaltige Spekulation".

It is true that it is useless to look for the millions of years and for the fossils and coal deposits of geology in the condition of Gen. $1: 2$, if we take this situation as preceding the lexaemeron, because there were no plants and animals then.

In the meantime we are confronted with the fact that according to geology whole races of animals have been extirpated long before man appeared on the scene. Usually Gen. $3: 17 \mathrm{f}$. is understood in the sense that death in the animal world first appeared after the fall of man. Another view is that death in nature (plant and animal world) is a normal phenomenon. Cf. De Bondt in Het dogma der kerk, p. 238: "For man death is the wages of sin. Because of the sin of man the earth is cursed. But separate therefrom we must accept death as the end of life in the plant an animal world. Even man had no eternal life in paradise, let alone plant and animal" (translated).

Before I venture a solution attention must first be given to the work of the six days.

C. GEN. $1: 3-2: 4 a$.

\section{THE WORK OF THE SIX DAYS}

a. The meaning of the word "day".

The basic problem here is the meaning of the word "day". Right through the history of exegesis there have been different views. 
The day must always be seen in connection with the week of creation. Must the idea of day or week he taken literally and is the length of a day the same as that of our day (provided we do not live at one of the poles)? (G. Ch. Aalders regards the day as real days, although it is a reality which is totally different from our days, so that it impossible for us to determine their length. They could have heen longer or shorter than our days.')

Aalders also stresses the fact that no adequate description of the divine work of creation is given. "There is every inducement (aanleiding) even to regard the use of the word 'day' as an anthropomorphism: the reality of the divine rhythm in the preparation of the world, of the sequence in the separate deeds of creation, of the appearance of the time dimension... could best be brought to expression for us human beings by the use of the word 'day'. $\left.{ }^{2}\right)$ To my mind Aalders has by this sentence revealed the Achilles-heel of his whole idea about the days of creation. N. H. Ridderbos aptly says: "If we have reason to call the use of the word 'day' an anthropomorphism why does this not apply to the arrangement $6+1$; why cannot the creation-week be called an anthropomorphism? $\left.{ }^{3}\right)$ Once it is acceded that we have to do with anthropomorphisms we should be extremely cautions in our definitions.

\section{b. The framework or cadre-hypothesis.}

This hypothesis believes that the arrangement of seven days is intended as a literary form. It was current already in the works of Philo, Origen, St. Augustine. Nowadays it is popular with Roman Catholic authors, but it finds favour also in the eyes of Protestant writers. ${ }^{4}$ )

N. H. Ridderhos is of the opinion that this is particularly important in the form given to it by $\mathrm{A}$. Noordtzij in his work Gods Woord en der Eeuwen Getuigenis (second edition, Kampen, 1931, p. 111 f.).

Noordtzij contends that it was not the intention of the inspired writer to describe the course of the natural process and that it is evident from the way in which he groups the material. This grouping is also found in other parts of Scripture, e.g. the different order of the plagues in Egypt as given in Ps. 78 : 44f. and Ex. 7-11; the different order of facts in Gen. 1 and 2 etc. ${ }^{5}$ ) The six days are evidently meant to be the sum of two trios. The word "day" means nothing else than day as it is experienced by man, more in particular by the writer and his environment.

N. H. Ridderbos is in agreement with Noordtzij as far as the main features of the hypothesis are concerned. He points out, however, that none of the cases cited by Noordtzij offers a perfect parallel to what 
Gen. 1, seen in the light of the framework-hypothesis, presents. His answer is that such complete comparison can hardly be expected of Genesis 1 in view of the unique character of this chapter. The examples used are all of them taken from historical accounts. But the "history" Gen. 1 offers is unlike any other of its kind.

I am in full accord with this, but wish to add that some of the examples are taken from poetry (e.g. Ps. 78) in which a historical sequence is not to be expected. My main objection to the frameworkhypothesis, however, is that it fails to supply an adequate motivation for the fourth commandment.

N. H. Ridderbos says that the argument proposed by Noordtzij is an illusion, namely that only the person who accepts the frameworkhypothesis can do justice to the idea of the sabbath as presented in Gen. 1. He acknowledges that on the basis of the framework-hypothesis one cannot state the matter as it follows from a literal interpretation according to which man should he the "imitator" of God, working six days and resting on the seventh day. He offers the following solution: Things may have happened in the following way: God decreed (when we do not know I the ordinance of the sabbath. His purpose nas that man should follow in His footsteps - sabbath is rooted in creation. In this connection God designated the seventh day as the day of rest. Thus the number seven became a sacred number, the number of the completed cycle. $A$ s a result the revelation concerning creation assumed the pattern of seven days. And the rationale of the fourth commandment as formulated in Exodus 20 presupposes this pattern. Further arguments for his theory Ridderbos deduces from the difficulties of realistic conceptions.

The motivation of the fourth commandment according to the framework looks like putting the cart in front of the horses. In this case God "imitates" the week of man.

The advantage of this hypothesis for the adherents thereol is that no difficulties in respect of natural science can arise. If it is not the intent of the writer to tell us what really happened, be it in anthropomorphic language, there never can be any conflict with science.

\section{c. The "age-day" theory or "moderate concordism".}

The restitution theory did not succeed according to Ramm because geology did not only require a huge draft on the bank of time but the rocks presented a sequence among themselves. Fossils are buried in these rocks and were a key to interpreting their sequence. The restitution theory could provide time but could not explain the sequence.

Ramm's theory regards the days as periods of time and explain 
them metaphorically and not literally. It is pointed out that in the first two chapters of Genesis the word "day" is used in five different ways: (i) in verse 5 it means daylight and (ii) a day marked out by an evening and morning; (iii) in verse 14 it means daylight in contrast to night, and (iv) in the expression "and for days" it means a twenty-four hour day; ( $v$ ) in Gen. $2: 4$ it refers to the entire period of creation.

These periods-Ramm continues-are not necessarily equal. They are as long as was required to accomplish what should be accomplished. The days of Genesis, further, need not fit any tight geologic scheme. This theory could be called a moderate concordism.

Ramm does not want this theory to be labelled "disguised theistic evolution", because it accepts progressive creation. "Theistic evolution accepts a creation from within. In theistic evolution there is a continuous line from the original cells on the prehistoric waters to man. All divine working is immanental in nature. But progressive creation teaches the transcendental activity of God. There is no continuum of life from amoeba to man, but the great phyla and families come into heing only ly the creative act of God".

If the objection is made that the order of the days and the geological order is not the same, Ramm says that the order in Genesis might be part chronological and part logical and each day may have overlapped the next. ${ }^{6}$ )

I can agree with Ramm in a great measure but cf. infra. When the account of creation is taken as analogous to prophetical literature, it should be remembered that it is difficult to detect a strict sequence. This criterium should be combined with all the hermeneutical principles which we discussed in $\S$ II. In the foreground is the fact that we have to do with a profound mystery. Secondly it has to be kept in mind that we have to explain the kerugmatic description of facts which were witnessed by no man. Thirdly, the Bible does not provide exact scientific concepts.

\section{d. The "prophetical" or protological interpretation.}

Personally I favour another interpretation of which N. H. Ridderbos gives a hint when he says: In prophetic and apocalyptic writings it is a common thing that events are telescoped, grouped and arranged in a given manner. ${ }^{7}$ ) This phenomenon should make us sympathetically disposed towards the jdea that in Gen. 1, which does not describe the distant future but the unimaginable past, we can expect to encounter the same idea. At this point we may mention that events which are separated from each other hy centuries are said to occur in "the day of Jahwe", while the same expression can also designate a definite point of time, 
namely the final day of judgment. The day of Jahwe certainly does not last for centuries in which the sun never sets, but is a prophetic compendium of events which are far apart chronologically.8) The "last hour" of J John 2 : 18 has lasted for nearly two millennia now.

Elsewhere I have pointed out that whereas prophecy has to do with eschato-logy, the account of creation deals with proto-logy. Now, if prophecy has to do with things that will really happen, but will be grasped ly man in its full significance only when fulfilled, mutatis mutandis the same applies to proto-logy, the prophet looking backwards over vast spaces of time.

On purely exegetical grounds one cannot go further than to state that the days are working days of God, but if natural science in its different ramifications teaches that millions of years have elapsed, there is no other conclusion, given the validity of the conclusions of science, than that immense periods have been contracted into six "days". This is exactly what happens when a telescope is used. If we further hold to the Scriptural truth that cvery new creature owes its existence to the divine creative word, we also notice the rhythm in the work of God and after each day-he it ever so long-something radically new comes into existence. Then we accept the days not as a scheme but as a prophetic reality. It is perhaps needless to stress the fact that in this case the idea is certainly not that the light shone throughout these "days", hut that periods of time (with their succession of days and nights) have been telescoped into one day. According to this view there is no difficulty with the fourth commandment.

c. Other features of the six days.

1. If Gen. 1 : 2 depicts a condition that is not merely devoid of form and life, but also something "unheimisch" (cf. supra) it follows that in the work of the six days, especially those of the first three. God puts a boundary to each of the phenomena which impede life (darkness, the waters above, and the waters as covering the ground).

2. In line with the inadequacy of the account lies the conviction of e.g. H. Bavinck: On every day of creation much more happened, than the sober words of Genesis lead us to expect. Creation was a series of tuemendous miracles, which the narrator pictures in one generalisation without going into details. As in the decalogue one single sin includes within itself many others, so in the story of every day of creation only the most important facts are described, namely those things that are the most important for man as the lord of the earth and the image of (iod. $\left.{ }^{9}\right)$

3. In the work of the six days a certain progression is to be 
noticed. The result is a great diversity-God is Hammabdil, the One who separates, but Scripture also stresses the unity of God's work. All the creatures, including man, have a relationship with the earth. At the divine creative word they all come out of the earth or the waters. In the case of man there is still something special (cf. infra). It is clear that all is working up to man who is the crown of creation. Some scholars speak of a prefiguration of man in everything that precedes him. Man is in a certain sense a microcosmos.

An exegete such as the Rev. J. C. Sikkel was of the opinion that God could have used the material of the foregoing to create the following. In connection with plants he says: "In the raw materials (grondstoffen) of the earth are found the basic powers and forms out of which the plants as higher heings are formed by God... The plants themselves ascend towards the higher creature." In connection with animals: "There is nothing against lout everything in favour, that the bodies of animals, by the creative act of God are built mainly from the organic, 'living' matter of the earth. Plants did not change into animals but as far as their bodies are concerned they were built out of organic material... Therefore, every following creature, in its creation as organism, is connected with the former, hecause every former creature in the counsel and work of God is determined by the following. The first creatures, although with their own essence in their own forms, are prefigurations (vóórgestalten), which in their turn are created with their own essence and form through the creative Word of God." In connection with man Sikkel says: "The soul of the animal is in the creative work of God a preformation towards the soul of man which is of a higher form, as the animal body is preformation towards the body of man, and as the plant is preformation towards the animal etc... The lower creature however, does not ascend out of its essence to a higher essence, but in his material and formal essence is subservient to God in His creative purpose. ${ }^{10}$ ) Unity and diversity, therefore, are the keynotes of the work of the six days.

4. A point on which one should be very clear is the relation of creation and the providence of God in the first and second chapters of Genesis. Some scholars (e.g. Lever) believe that the only real creative fact was in the beginning. From there and further on everything develops in what is called a "general evolution" under the Providence of God. The word which God speaks is interpreted as the guidance of God in the course of evolution. If we read Gen. 1 in the light of John 1, however, much more weight has to he placed on the wajjómèr (and said) of God. Instead of general evolution I would prefer the term progressive creation. H. Bavinck said more than half a century ayo: The creatio secunda (work 
of the six days i already stretches forward to the work of conservation and government, it is already partly conservation and no pure creation any more... But in any case the work of the six days must he reckoned to the creation."1, The decisive houndary is the creation of man. If an unlimited (evolution is accepted, it may be expected that man may develop) into something higher again. But nowhere in Scripture is there any warrant for this idea. Christ became man and with man he builds His kingdom. Brumner strikes the right note when he says: "Ilie Gefahrenzone ist bereits ïhersehritten no man Schöpfung und Erhaltung identifiziert." It may lead to pantheism. But Brumner does not draw the line of demarcation with the creation of man when he says that God "immer wieder schöpferisch, Neues schaffend tätig sei" in a world which He has already created and now governs. He quotes as example Ps. 139 : 13. But certainly this is radically different from creation in Gen. I where something absolutely new is the result. In Ps. 139 the result is only another man. ${ }^{12}$ )

For this reason there is danger in the words of Van Niftrik: "The providence of God, the conservation and governing of man and the world hy God: that is also creation, continuous creation, creatio contimua. God is elernally the Creator."

Van Niftrik agrees that the term can be used in pantheistic sense and therefore narns: the difference between creation and providence may be eliminated. All pantheists-thus Van Niftrik like to eliminate this difference for the simple reason that in creation we find the idea of a pure heginning and this is a stumbling block to pantheists.

Also for this reason-says Van Niftrik-the idea of creatio continua is a danger in that it tends to make us forget that creation which is governed by God is a fallen creation. The formula may foster the idea that creation comes as new out of the hand of God continually so that it is still undefiled. It is strange that Van Niftrik wants to keep the term in spite of all the dangers. ${ }^{13}$ )

\section{I). Conclusion on the exegesis of Gen. I.}

With due consideration for the mystery of revelation, especially in this chapter, and for the hermeneutical rules that pertain to this matter (cf. $\$$ If $)$, the view of Ramm apeals to me more than any other. I would like to take over his term "progressive creation" also, provided that the idea of fiat-creation is not excluded. As far as Gen. $1: 2$ is concerned I am convinced that honest exegesis cannot deny the fact that there is something "unheimisch" in the different terms which are used. The reader of this verse in the time of its composition and for centuries after that would undoubtedly have appended the same meanings to the 
words which they have in the rest of the Old Testament. The Old Testament does not tell us explicitly where this tóhâ wabohâ-condition comes from. In the whole of the old Testament (and even in the whole Bible) very little is said concerning the origin of evil. Barth, Brunner, etc. contend that the few texts in connection with the fall of the angels are of such a dubious nature that no doctrine can be grounded thereon. Van Niftrik states apodictically in the year 1961: "The devil is no fallen angel". What we know in any case is that this power of evil was there when man lived in paradise. It was signalized in the lesomrah ito keep) of Gen. 2 : 15 and appears in Gen. 3.

Very significant is also the fact that in the prophetical and hymnical portions of the Old Testament there is constant reference to the "battle" of Jahwe with the monsters of "chaos". The difference with pagan mythology is that Jahwe handles these monsters according to His sovereignty. In reality there is no battle but only the commanding word. If this is the case the exegete has to reckon with the fact that the condition of Gen. 1 : 2 did not end before the first day. What about the tanninim of the fifth day (cf. the notes on the work of the fifth day infra)? Is it far fetched to reckon with demoniac factors even during the last three days?

It may be asked: What then is the meaning of the "good" and "very good" after the work of almost every day? The answer is: even of this world, under the curse of God, a world of sin and death, Scripture says: The earth, o Lord, is full of Thy mercy (Ps. $119: 64$ ); the earth is full of the goodness of the Lord (Ps. $33: 5$ ). We may add Ps. $36: 6$; $57: 11 ; 104: 24 ;$ Is. $6: 3$ ).

Von Rad aptly remarks that the word $t \hat{b} b$ does not so much designate ar aesthetic quality than the idea of what is "Zweckmässig". He also refers to Ps. 104.

It should also be kept in mind that the "good" and "very good" apply to the work of God. "Ob aher Satan zu ihnen noch irgendeinen Zutritt hatte, oh es dämonische Querwirkungen gab oder nicht darïber sagen diese Stellen schlechterdings nichts aus" (Sauer).

The main oljection to this view is the preconceived idea that the disruption of creation is solely due to the $\sin$ of man. As proof Romans $8: 20$ is cited. It strikes one, however, that commentators are not very outspoken on the point that man is the one who subjected the creature to nothingness.

Godet in his commentary says that there is something strangely mysterious in the apostle's language, which he might easily have avoided by saying: by reason of man or by reason of us; then, does the term: "he who subjected", apply well to man, who in this event, so far as 
nature is concerned, played purely a passive part? This has led one critic (Hammond) to apply the term to Satan, the prince of this world (as Jesus calls him ) who either by his own fall or hy that of man, dragged the creation into the miserable state here described. The only room for hesitation, as it appears to Godet, is hetween the latter two meanings. He sees no room for applying the term to God.

H. N. Ridderbos in his commentary follows the same line. The question that has been treated repeatedly whether "by reason of him" denotes Adam or God is of no cardinal significance, although the active form of the verl, seems to point more to the second than to the first possibility. The participle points to a divine decree; dia points to the will of the $A$ uthor.

'To sum up: honest exegesis cannot deny the fact that the condition of creation before the fall of man was not idyllic. Although Scripture does not state explicitly what the cause of this condition was we have to accept the fact. Tentatively we may venture to speak of demoniac influences long before the fall of man.

This is no restitution theory, because this theory has to accept that the tóh û-wúbóh û condition preceded the hexaemeron and that a complete world existed then.

\section{F. The kerugma of the seven days.}

I do not share the opinion of some theologians that the story of creation has no cosmological significance whatsoever and that every. thing has to be interpreted in a soteriological sense. If the writer speaks of the two great lights, he evidently has in mind the sun and the moon as even we see them every day. We must be on the alert for a purely allegorical exegesis.

This, however, does not detract from the fact that Gen. 1 and 2 also preach something, especially when viewed in the light of the whole of Scripture.

The first day-time to live in. Gen. $1: 3-5$.

And God said-on the very first day the majesty of the Word of God is clearly exhibited. Very explicitly it is said that it is not a force which derives from the things themselves, but that the Word of God is the creative force. "Das ist das Urwort welches das Schweigen der Eiwigkeit brach: des Herrn Gebot (Ps. $33: 9$ )".'3) Without any resistance the word is obeyed. The unconditioned sovereignty of the Lord is evident. "Kein philosopisches Nachlenken wird den redenden Gott finden" (Zimmerli). The thoughts of the Christian are immediately concentrated on John 1 : 1f.; especially verse 3 . Cf. also John $8: 12 ; 1$ John $1: 5$. 
The next great kerugma is: sun, moon and stars have nothing divine in them. If it is the will of God there can be light without the heavenly bodies. They are only media that point to Him who is light and in the Person of Christ made that light to shine into the darkness of this world (2 Cor. $4: 6)$.

\section{Let there be light...}

What a profound revelation that the creative days are opened by the influx of light in the tóhâ wábóhâ-condition. L,ight is also a creature of God and no emanation from Him. And God separated the light from the darkness. All God's works are done in the light of day. The light is good, but not the darkness. The cross of Christ preaches the depth of darkness. but at the same time darkness is conquered by the cross.

Darkness is also subjected to God. 'This emerges from the fact that to darkness is given a name by God. The naming is a sign of Lordship. Night is destined to vanish (Rev. $21: 26 ; 22: 5$ ). Isaiah $45: 7$ denies that darkness is a separate power opposed to God. It is also a creature. Gen. I says: God's purpose is to work salvation.

Day is the unit of time that God has destined for mankind to live in; the day which is the name of light and expression of the goodness of God. We live by the day and expect the Day.

The second day-space to live in (Gen. $l: 6-8$ ).

The main theme here is ordering, division, the placing of houndaries (cf. the separation of light and darkness). In the tohk $\hat{u}$ wáboh $\hat{u}$-condition waters are mentioned and tehôm which is also a flood according to some. In the Bible water is not only $\mathrm{H}_{2} \mathrm{O}$ but it also denotes something that is ominous. The life of man is threatened by waters, not only by the waters on the earth but also by the waters from above.

Here we have an example of the use of the terminology of the times of the Biblical writers. N. H. Ridderbos is right when he says that it is useless to apply a forced exegesis in order to explain the Hebrew propositions mittachath le and méal le as denoting the waters at the bottom and the top of the firmament: The prepositions mean "under" and "above". It must be kept in mind that the firmament is "in the midst of the waters" and that it divides waters from waters. The author speaks in the terminology which was current in his day and he is not corrected in a direct sense (cf. $\$$ II). The general view in his time was that the celestial arch separated the waters of the heavenly ocean from the waters heneath. As soon as God takes the dividing line away the waters from beneath as well as from above again transcend the boundaries as in Gen. 7 : 11,8 : 2; cf. also Ps. $148: 4$; Is. $24: 18 .{ }^{14}$ ) God by His word 
sees to it that the waters of the "heavenly ocean" and the ocean on earth merge. Cf. Ps. 89 : 26.

The message of this portion of Scripture is: God created the ordinances of heaven and earth hy His Word.

\section{Ind God called the firmament "heaven".}

Day is the name of the time unit in which we live; "heaven" is the name of the space under which we live, the firmament, seen by the ancients as an arch, token of Gods faithfulness.

The third day-the good earth (Gen. 1 : 9-13).

Also the waters on the earth form a menace, cf. Ps. 104:7-9; Jer. 5 : 22. But if this power of "chaos" hecomes rebellious God will quieten it (Ps. $39: 10$; Job $26: 12$ ).

The separation between waters and dry land means that God prepares a dwelling place for animals and man. "Das unheimliche der unheimlichen Meeresmachte ist verschwunden." (Zimmerli).

The main theme in all these verses is the clear distinctions which God makes. In the reports about primeval times pagan cosmologies revel in the description of mixed, demoniac entities. Here all these phantasies are rejected. God is not a God of "chaos" but of order. In Mosaic law all kinds of laws against unnatural mixtures are found.

God by His Word supplies the earth with the power to produce new life. The lordship of God is proclaimed over nature. Deification of the earth is precluded. In the plants the mystery of life is seen for the first time.

The fourth day the service of the bearers of light (Gen. 1 : 14-19).

After the ornamentation of the earth follows that of heaven. It is significant, when viewed against the pagan background of the Ancient East, that the heavenly bodies are called creatures. And that they do not have a dominating function but a serving one. That they are not the creators of light but only the bearers (me 'órót) thereof. They reflect the light of God who is Light Himself and revealed Himself in Jesus Christ as the Light of the world. When Gods purpose is realized these light hearers have hecome redundant (cf. Rev. $21: 23$ ). ${ }^{15}$ )

Not on the sun or the moon but on earth has happened and will happen what is truly great, cf. Ps. 8. "Gewaltig ist der Sonne und dennoch tut Gott sein Grösstes nicht aul die Sonne, sondern auf Erden, unter der Sonne" (Zimmerli). In the fulness of time God sends His Son to this earth. "Von da her bleibt es bei der Rangordnung die hier gegehen ist, trotz aller Naturwissenschaft." 
I agree with Zimmerli when he says that these verses contain a great liberation. ${ }^{16}$ ) Man is called upon to penetrate deeply into the world of the stars. But the planets may not be deified (cf. Is. 47 : 13f; Jer. $10: 2$; Job $31: 26-28$ ).

Contrast this with the conceptions of the Ancient East. In Babel the stars dominate the whole life of man. The thought of the Ancient Near East is under the ban of the cyclical movement of the stars (cf. Deut. 4 : 19). This meant a real danger to Israel, cf. 2 Kings $23: 11$ f.

The fifth day--water animals and birds (Gen. 1:20-23).

The kerugma in these verses is that the menacing powers in the waters above and the waters beneath are so completely under the control of God that it is safe for all kinds of living beings to live in these border zones.

It is especially significant that the sea-monsters, the tanninim, the dragons, are mentioned specifically. Elsewhere in Scripture they represent the evil powers in the waters. Here it is said explicitly that they are also created by God. Veneration of animals is cut at the root--no chaos dragons, no holy animals--all are creatures of God. ${ }^{17}$ ) Von Rad remarks that it is significant that the word bar $\ddot{a}$ ' is used here again for the first time after verse 1 (not in the case of plants). bir $\ddot{a}$ " is "jene gewichtigc Bezeichnung sonderlingen und ausschliesslichen göttlichen Schaffens", and is used again when the creation of man is recorded. Applied to the tanninim, the sea monsters, this is of special significance. "Von ihnen soll es im besonderen nochmals unterstrichen werden, dass sie restlos hineingehören in die geschaffene Welt und keinerlei eigene Macht gegen ïher Gott besitzen." (Zimmerli).

Of special significance is the fact that here for the first time the divine blessing is pronounced over created things and notably in connection with the multiplication by birth. It is a wonder that animal life can produce new life out of itself, but this does not elevate it to the divine sphere. This was the belief in the Umwelt of Israel. The Canaänites for instance called the young of sheep) and goats "Astarte", the same name as that of the goddess of fertility. Something divine is seen in the offspring. Here Israel is taught that the mystery of vitality may not be interchanged with the mystery of divinity. At the same time the usc of the word "bless" shows that the creative word of God is not cold and abstract, but the voice of love. This will become perfectly clear in the creation of man. ${ }^{18}$ )

The sixth day-the "comrades of man" and man himself (Gen. I : 24-31).

The action of the earth in bringing forth the animals is again 
subordinated to the creative word of God. The word of God stands in the leginning and in verse 25 it is said explicitly: and God made...

\section{The creation of man.}

Verse 26 brings us to the consummation of God's creative work. None other of the creative works is described so elaborately. The summit of the pyramid is reached. No word of command but a word of "Ueberlegung". Now for the first time there will be an entity that is created in the image of God. And the life of this being will be that he keeps near to God.

The following words of Noordtzij should he kept in mind: "The first part of the creative deeds of God is described as a stream that is flowing evenly. As by itself one thing emerges from the other out of the 'chaotic' mass which is impregnated by the Spirit of God (but cf. on this point $\$$ IV. A. S.d.T.), for which nothing else is needed than a creative word and nothing more... all things were included in the "chaotic" mass. They just waited for the creative word of God to emerge therefrom. But the whole picture changes as soon as it concerns man. In Gen. I : 26 we have a moving anthropomorphism which can only be justified because and in so far as the inspired writer wants to bring lis readers deeply under the impression that what follows is absolutely unique in the total of the creative deeds of God."19)

The seventh day (Gen. $2: 1-3$ ).

The kerugma of this day is so wide and deep that it is impossible to do justice to its significance in this short treatise. We may refer to the different commentaries. Zimmerli has some striking comments on this day, which was hallowed by God: In the "rest of God" it becomes clear that the whole creetion has to recede behind the Creator. To the sabbath day one approaches as to a possession of God. The whole creation has its zenith in the day of the Lord.

\section{EVOLUTION ANI) EVOLUTIONISM}

In connection with the connotation of these words there is much confusion, because different realities are covered in popular thought by the term "evolution".

Lever proposes that the term "evolution" should be used only for the description of phenomena comprising change of structure. Different herefrom is the evolution hypothesis which presumes a connection (samenhang) on definite grounds and explains therewith certain details, or contains a definite conception in connection with the mechanism, the 
causes, of the phenomena of evolution. These two words therefore belong to the indispensable conceptual apparatus of modern natural science.

With evolutionism the case is different. This is a definite philosophical (wereldbeschouwelijke) vision on the structure and the origin of this reality, especially of the world of organisms. Not every biologist would like to be called an evolutionist. This applies especially to the Christian, because evolutionism had its origin as a reaction to and as sulistitute for the Christian helief in "God, the Father, the Almighty, Creator of heaven and earth".

Some characteristic and historically important trends of evolutionism are: 1. The classical materialistic evolutionism; 2 . the deistic evolutionism; 3 . the theistic evolutionism, all of which Lever regards as unsatisfactory.'

The Reformed Ecumenical synod of 1919 alecided on the following guiding principles (art. 89):

1. The historicity of revelation in Gen. 1 and 2 must he maintained undiluted. Neither of these Iwo chapters gives any grounds for a symbolic or visionary interpretation, of for regarding the account of creation as an allegorical mylh.

2. This true and ahsolutely authoritative account by God of His creation has been given (o) us in a form intelligille to men, so that, although it gives no adequate description of this I)ivine act, it nevertheless provides sufficient yround for us 10 know and glorify $\mathrm{Him}$ as our Creator.

3. By accepting the historicity of Gen. 1 and 2 , the Church repu. diates any concept of evolution which a) completely eliminates God, b) regards $\mathrm{Him}$ as dependent on the process of so-called creative evolution, or c) relegates $\mathrm{Him}$ to the position of merely incidentally intervening in the natural course of evolution.

Revelation in terms intelligible to human beings imposes on the Church humility and discretion in making all kinds of pronouncements in connection with scientific matters."

A commission appointed by the Ref. Ecumenical Synod of 1953 reported to the Synod of 1958 , the members being the professors Lever, Polman, Jonker, Oosterhof, Gispen, all from the Reformed Churches (Cereformeerde Kerken) of the Netherlands.

In connection with the first of these "guiding principles" the commission comments that they have no ohjection to it, but they regard the wording as vague and not quite clear. There are, indeed, no indications of the concrete implications of such a principle. They wish, however, fully tn endorse the amplification of this principle, as given in the relevant report: "That synod leave the detailed implications to be studied in 
collaboration by theologians and scientists who accept the infallibility of God's Word, seeing that in the past no Reformed Church has pronounced its views in connection with this matter in such a detailed way (as is suggested in the South African report). Synod was therefore evidently reluctant to impose a definite exegesis. It does, accordingly, not support either the cadre concept (A. Noordtzij, subsequently N. H. Ridderbos) or the more literal interpretation of the South African report in connection with the actual sequence of events in God's creation. Synod does, however, repudiate a symbolic or visionary interpretation and the idea of an allegorical myth, as having no grounds in these chapters."

With reference to the assertion that the Reformed Ecum. Synod has in the third general principle not sufficiently distinguished its standpoint from that of theistic evolution, the commission proposed to consider somewhat more fully exactly what this principle lays down. Careful scrutiny reveals that Synod was reluctant about peremptorily rejecting any concept of evolution as such. Similarly, Synod has refrained from intimating what concept of evolution would be acceptable. Synod has merely directed the attention of the Churches to the fact that acceptance of the "historicity of the revelation in Gen. 1 and 2" implies that a Reformed scientific researcher should observe that Divine creation should be the starting point of scientific investigation. Whether and to what extent in the development of what had been created God has made use of evolutionary processes, is for the believing researcher to establish.

With regard to the three concepts of evolution which are rejected by Synod the commission says that closer study of the three rejected concepts brings one on the right track in order to detect the criteria which have been applied in the rejection.

A. (The first type of evolution can be disregarded for the purposes of this treatise).

B. The second type is that which conceives of God as dependent on a process of so-called creative evolution. According to the commission this evidently refers to a kind of evolution sponsored e.g. by Lamarck. God gives the initial impetus to the evolutionary process, which subsequently proceeds autonomously, independent of divine control, under the causality of an immutable law of nature. This theory does not accept any fundamental boundaries between aspects of creation.

C. This concept the commission regards as an amplification of $B$. It accepts that aspects differ essentially and were added by God during an autonomous development, by means of His intervention in the evolu. tionary process which is directed by natural forces.

The three concepts have-thus the commission-this in common that they assign to natural forces independence and complete autonomy. 
In the first it is an autonomy which completely repudiates the existence of God; the second and third concepts attribute the creation of natural forces to God, only to regard Him as losing control of the subsequent autonomous development.

The commission continues: The intention of Synod's pronouncement was emphatically to repudiate the fallacy of autonomous natural evolution, and assert as opposed to it the belief that God as Creator of all reality still continually maintains and directs it. Any concept of evolution which denies the latter is unacceptable to a Christian believer. Synod, while emphatically repudiating only such evolutionistic concepts which deny the absolute sovereignty of God, left the feasibility of some form of evolution an open matter.

The commission is convinced that their reasoning and that of Synod is entirely in the line of the teaching of Abraham Kuyper. In his address on Evolution in 1899 he emphatically condemned the idea of a "purposeless and mechanically constructed cosmos". This was directed against evolutionistic concept $A$, which attributes to natural forces an independence of God. That Kuyper would also have rejected the other two concepts is evident from his rejection of supranaturalism (cf. Berkouwer, De voorzienigheid Gods, 1950, p. 229 etc.).

Kuyper was therefore opposed to any form of evolutionism whatsoever. But that does not prevent him from realising that faith in God as Creator does not imply that the phenomenon of evolutionary growth does not exist. Kuyper says that if it had pleased God, instead of creating differentiated types, to allow types to develop into other types, by endowing the lower with the potentiality to develop into higher, creation would have been no less sublime. Kuyper also speaks of "God's evolutionistic creation".

The commission concludes that, seen in this light, Synod wisely did not pronounce an opinion on the idea of the so-called theistic evolution, because the term "theistic" precludes that which was repudiated in the rejected theories. The commission does not deny the possibility that this concept, despite its commendable starting point, may give rise to theories not in harmony with Scriptural revelation, but this possibility does not justify a synodical repudiation of the concept as such.

Synod was advised to change the wording of the third conclusion to read as follows:

"Observing the historicity of Gen. 1 and 2 implies inter alia an acceptance of Divine creation, maintenance and government of the entire world, and accordingly implies that the Church should repudiate any concept of evolution which a) entirely eliminates God, b) regards Him as dependent on the process of creative evolution, or c) regards Him 
as merely incidentally intervening in the natural course of evolution.

Generally, because it has to preach the Word of God, which is not a scientific treatise and which should not be bound to any particular exegetical exposition, the Church should observe the utmost discretion in making all kinds of promouncements in connection with scientific matters."

This report was accepted by the Ecumenical Synod of 1958 and also by the General Synod of the Gereformeerde Kerk in Suid-Afrika in 1961, presumably also by the other member synods. I have quoted extensively from this report because it has standing owing to the acceptance by church bodies and because it is of very recent origin.

Delleman says: "I deem this report as very important, because it clearly rejects all fundamentalistic tendencies in the international and national Reformed persuasion (gesindte)." He deplores the fact that Synod did not decide more distinctly for the kerugmatic viewpoint, which means that there should have been a clear distinction between the historicity of creation and the kerugmatic narrative style in which the deeds of God are reported in Scripture. ${ }^{2}$ )

I am in full agreement with the resolutions of the ecumenical synod and also with the remark of Delleman cited above. It is noteworthy that not even the so-called theistic evolution is rejected, a theory which Lever classifies amongst the different evolutionisms as a third category, which had its origin in orthodox Christian circles. The adherents of this theoryaccording to Lever-are impressed by the discovered rule of law in nature and in a certain sense they also teach a degree of autonomy of the forces of nature. In addition to this they also wish to accept that the personal God can exert influence and further that there are fundamental boundaries in this reality. The synthesis is found therein that God during the history of the earth at definite moments intervened in nature from the outside to add new structures or aspects, or to change the course of things. Lever sees some dangers in this viewpoint, because of which he rejects it. 1. A synthesis is constructed between ideas that are irreconcilable, viz. between the belief in autonomy and the belief that God governs all things, with the result that the omnipotence of God is restricted in a measure. 2. According to this view the acts of God in this reality become scientifically demonstrable. Theism and evolution are in their deepest sense irreconcilable, so that even the name "theistic evolution" creates confusion. ${ }^{3}$ )

Lever's own view is that only in the vindication of the absolute dependence in creation and development of this world on God, a way is opened for a Christian approach to the problems concerning the origin of things. He therefore presents the idea of general evolution, that is to say: in the beginning God created into this universe all aspects 
which under his Providence develop through the ages, while God directs this evolution in such a manner that when the time is there for the following and higher creature, he (it) comes into being.

My objection to this idea is that only the first act of God "in the heginning" is really creation-all the rest is development under the Providence of God. Lever is very apprehensive of the idea that God intervenes incidentally and that his work could be pointed out. But when we speak about progressive creation this does not mean that God intervenes with a fiat-creation merely incidentally, a view rejected by the Ecumenical synod. After the fiat-creation development under the providence of God certainly takes place, but it is clear from the often repeated "and God said" in Gen. 1 and from the gospel of John ( $1: 3)$ that everything that is was created by the Word of God. This is a special intervention of God which does not mean that outside of this creation was left to itself, because the providence of God was there all the time. Kuyper speaks of an "evolutionary creation" by God, by which he means that God first has his divine plan which is executed by His omnipotence. Kuyper's term, to my mind, futhermore stresses the fact that in the process of development God is also creating through His omnipotence. Seen in this light each day of creation has a definite end and on the following something entirely new makes its appearance.

The danger of accepting a "general evolution" under the Providence of God is that it may imply that this process goes on till the consummation of all things and the possibility is not explicitly excluded that after man something new and higher may evolve. Scripture is very outspoken, however, that with man the last creature of God makes His appearance. Christ became man and through the liberation of mankind the whole creation will be saved (Rom. $8: 19,21$ ). Lever's position is to be understood as a reaction against supranaturalism which believes that the laws of nature are an entity in themselves and that God intervenes merely incidentally. But this reaction leads him too far away from the idea of creation proper.

I have great admiration for the courageous effort of Lever to suggest a new approach after the failure of fundamentalism and supranaturalism, but have three main objections: 1. In Lever's approach too much attention is paid to philosophy, which can say nothing about creation unless the knowledge is obtained from Scripture. For the relation of exegesis and philosophy see above. 2 . Too little is made of the creative activity of the Word of God. 3. Too little attention is paid to the rôle of sin and consequent degeneracy. 4. According to this view there is nothing which excludes a continuation of the general evolution till the end of this 
world, which may then also take place gradually and not in the way of a catastrophe.

Ramm prefers the term "progressive creation" which he opposes to what he calls "fiat-creation". He distinguishes four patterns of thought in connection with the origin of the universe: (i) fiat-creationism; (ii) progressive creationism; (iii) theistic evolution; and (iv) naturalistic evolution. Progressive creationism-thus Ramm-tries to avoid the uniformitarianism of theistic evolution and to preserve its sense of progress or development. ${ }^{4}$ )

It is difficult to see the difference between theistic evolution and his idea of progressive creationism because both evidently do not believe in fiat-creation after the first act of creation.

The present writer has objections to all the previously mentioned definitions. He would prefer to speak of progressive creation which does not exclude fiat-creation. That is to say: in the beginning God by a fiat of His omnipotence brought into existence "the heavens and the earth" creatio post nihilum whatever the condition of the product was.

But even after this there was fiat-creation, e.g. the famous fiat lux of Gen. $1: 3$. And every time in the heginning of a new day "God said". Sometimes there is just a division (as on the second day) but sometimes something entirely new (as in the creation of man). The definite end of creation is the end of the sixth day. Thus, even if the long periods of geology have to be accepted, the day of God ended at a certain point and started with something new. In the case of man there must have been only one at first, implemented by the creation of woman, else the rest of Scripture has no sense, cf. chapters like Romans 5 and Acts 17 (especially verse 26: out of one blood). Natural science cannot explain the origin of life after a period of lifeless matter or the origin of animals out of plants.

But Van Niftrik wishes to retain the term because the Old Testament has only one word (bárä) for creation and maintenance. Maintenance is continued creation. Creation takes place even now. Everyone of us was created by God on such and such a day."5)

It is true that in a certain sense God creates even now. Some Reformed theologians assume that the soul of every man has its origin in a creative act of God (the so-called doctrine of creationism-cf. Chr. Encyclopaedie, first edition, s.v. Creatianisme). Although I have serious doubt whether this doctrine is in harmony with Scripture it is quoted to prove that for a long time it was not regarded as unreformed if the creation of every soul by God is taught.

But it would be in harmony with Scripture to distinguish between the original creatio ex nililo (or post nihilum), the creation of the six 
days, where in most cases the created matter also plays a rôle (as well as providence if long periods have to be accepted), and providence proper after the work of the six days and during the seventh day, in which development takes place; but the summit reached in man is of such a nature that he lasts till the consummation of all things and nothing higher than him emerges.

It should be noticed that this is not in conflict with the decisions of the ecumenical synod mentioned above. What is rejected is that God intervenes merely incidentally. In the destinctions we have made there is nothing of Deism or of a deus ex machina. And at precisely this point the difference comes in. Only if the hexaemeron is taken as a framework is it possible to disregard the "and God said", which is of great importance if viewed in connection with John $1: 3$.

\section{NOTES}

$\$$ I.

A.

1. I) Is there a conflict between Genesis I and natural science? Grand Hapids, 1957 , p. $26,27$.

2) Das erste Buch Mose (Das Alte Testament Deulseh, Göllingen, 1950), p. $58-61$.

2. 1) Scheppingstradities bij de profeten, Ansterdam, 14.5, p. 110.

2) Van Gelderen in his commentary on Amos, Kampen, 1433, in loco.

3) Brongers, op. cit., p. 94.

4) Pentateuchtradisies in die prediking van Deuterojesaja, Groningen, 1956.

5) ibid., p. 8.

6) ibid., p. 11 .

7) ibid., p. $21 f$

\& II.

A.

1) Heilsgeschiedenis en heilige Schrift, Kampen, 1955, p. 115.

2) Gereformeerde Dogmatick 4, Kanpen, 1928, II, p. 4.57.

3) Kampen, 1958, 1II, p. 621.

4) De goddelijke openbaring in de eerste drie hoofdstukken van Genesis, Kampen, 1932, p. $171 f$.

5) Geref. Dogm., I, p. 427f.

6) II. N. Ridderbos, op. cit., p. 115.

7) Kanipen; 193], p. 105f.

8) Cf. also Polnan, Chr. Encyel. III, p. 622.

B.

1) C.. Vriezen in: Inleiding tot de Theologische Studie, Van Oyen e.a., Groningen, 1946, p. 39f. Also Van Niftrik - Kleine Dogmatiek 5, Nijkerk, 1961, ․ $77,78$.

2) Hoofdlijnen der Theologic van het Oude Testament, Wageningen, 1954, p. 116 , note 4. 
3) C. Greydanus, Schriftbeginselen ter Schriftverklaring. Kampen, 1946, 1.. 145.

4) Zır biblischen Ilermeneutik. (Theol. Studien, Evang. Verlag Zollikon, 1959 , p. $3-10$.

5) Ilet verloren paradijs, Kampen, 1925, p. 116 .

6) Itsid, p. 11 f.

7) Cf. Schilder - Een hoornstoot tegen Assen, Kampen, 1928, p. 44 .

8) Dogmatick, II, 458.

9) B. Ramm, The Christian view of science and Scripture, Grand Rapids, 1954 , p. 28.

10) C. R. H. Bremmer, Herman Bavinck als dogmaticus, Kampen, 1961, p. 210 Brunner is very outspoken on this point (Dogmatik, Zürich, 1950, II, 41): Wir täten gut daran, endlich einmal die jammerlichen Verschanzung hinter den hypothetischen Charakter dieser Forschungsergebnisse, diesen ïblen Trick fauler Apologetik, zu unterlassen und Forschungsergebnisse die von allen Forschern anerkannt werden, weil sie aul Beweis beruhen, auch als für uns verbindlich anzuerkennen."

C.

1) Cf. Noordtzij, op. cit., p. 112.

2) Cf. Bavinck, op. cit., II, 387.

3) Op. cit., II, 371.

1) Dogmatik, II, 1. 7,8

i) Introduction to the Old Testament, Grand Rapids, 1949, p. 156.

6) P. 12, 13.

7) P. 20, 21 .

\$ III.

1) Opmerkingen over Genesis I, Groningen, 1955, p. 24 f.

2) Dogmatick II, p. $444,445$.

3) Op. cit., p. 176 .

1) Op. cit., p. $208,209$.

5) Creatic en Evolutie, Wageningen, 1956

6) Ibid, p. J88I.

$\$$ IV.

A. B.

1) Barlh says: „mit eine der schlimmsten in der ganzen Bibel” (Kirchliche Dogmatik, III, 1, 1945, p. 112).

2) B. S. Childs, Myth and reality in the Old Testament (Studies in Biblical Theology), S.C.M.-Press, London, 1960, p. 3.

3) In Oud-Testamentische Studiën XII (Leiden, 1958), p. $214 f$.

4) Jbil., p. 223.

5) Op. cit., p. $36 f f$.

6) In: Die Natur im Alten Testament, Lund, 1941, p. 8.

7) O.T. Studien XII, p. 224.

8) (C. also the detailed exegesis of J. II. Scheepers in: Die Gees van God en die gees tan die mens in die Ou Testament, Kampen, 1960, p. 2466.

1) J. II. S(cheepers, op. ail., p. 251f. Cf. also Childs op. cit., p. $32 f$.

10) Op. cit., p. 33, note 2.

11) Op. cil., 1. $255,256$. 
12) Op. cit., p. 34, 35

13) Aalen, Die Begriffe „Licht” und „Finsternis” im A. T., im Spätjüdentum und im Rabbinismus, 1951, p. 10, note.

14) o. T. Studien, XII, p. 254.

15) E. Sauer - Vom Adel des Menschen, Gütersloh, 1918, p. 80 f.

16) Op. cit., p. $195 f$.

17) Cf. Noordtzij, op. cit., p. 108

18) Op. cit., p. $201 \mathrm{l}$.

19) Op. cit., p. 109.

20) De zonde, Kampen, 1960, part. I, p. 7 lff.

C.

1) Op. cit., p. 252,253

2) ibid., p. 252.

3) Is there a conflict...., p. 55 .

4) Cf. N. H. Ridderbos, ibid., p. 11

5) For more examples quoted by Noordizij, ef. op. cit., p. 117, N. H. Ridderbos Conflict, p. 37.

6) Op. cit., p. $211 \mathrm{f}$.

7) Confl., p. 38, 39.

8) Ibid., p. 39.

9) Dogmatick, II, 463.

10) Het bock der geboorten, Amsterdam, 1923, p. 85, 90f., 1406 .

11) Cf. Bavinck Dogmatiek, II, 410: The creatio secunda is partly conservation and not pure creation... But the work of the six days must be reckoned as belonging to creation.

12) Brunner, op. cit., p. 42, 43.

13) Zimmerli, 1 Mose 1-11, Prophezci, Zürich, 19.43, p. 41.

14) Cf. N. H. Ridderbos, Conflict, p. 44.

15) A. A. Manten in Koers (a periodical edited in Potchefstroom), May 1959.

16) Op. cit., p. 66.

17) A. A. Manten in Koers.

18) Zimmerli, op. cit., p. $72,73$.

19) Op. cit., p. 117.

$\S \mathrm{V}$.

1) Christelijke Encyclopaedie, Kampen, 1957, s.v. Evolutionisme.

2) Delleman, Wording van mens en wereld, Aalten, undated), p. 23, 24.

3) Op. cit.

4) Ramm, op. cit., p. 113.

5) Op. cil., p. 80 . 